
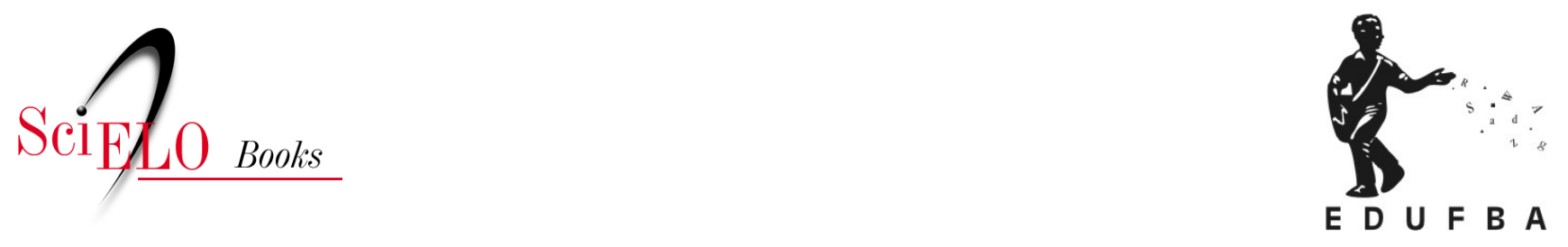

\title{
No terreiro processos encarnados de autoidentificação
}

\author{
Luciana Duccini
}

\section{SciELO Books / SciELO Livros / SciELO Libros}

DUCCINI, L. No terreiro: processos encarnados de autoidentificação. In: Diplomas e decá: identificação religiosa de membros de classe média no candomblé [online]. Salvador: EDUFBA, 2016, pp. 197-243. ISBN 978-85-232-2011-2. https://doi.org/10.7476/9788523220112.0007.

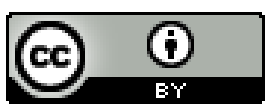

All the contents of this work, except where otherwise noted, is licensed under a Creative Commons Attribution 4.0 International license.

Todo o conteúdo deste trabalho, exceto quando houver ressalva, é publicado sob a licença Creative Commons Atribição $\underline{4.0}$. 


\section{No terreiro: processos encarnados de autoidentificação}

[A iniciação] muda a maneira que a gente vê as coisas, até a sessão de caboclo que a gente praticamente nem vê mais.

Foi como Marta respondeu à minha mensagem, em março de 2003, perguntando como ela estava após a saída da reclusão. Marta havia passado quatro anos como abiã no Ilê Axé Torrundê Ajagun e foi iniciada em dezembro de 2002, aos 47 anos de idade. Sua resposta parece simples, mas o que exatamente quer dizer uma mudança no modo de "ver as coisas", especialmente quando inclui a possibilidade de não ver? Durante os capítulos precedentes, algumas questões foram propositadamente deixadas de lado. Agora, porém é preciso retornar a elas. Argumentei que os processos de autoidentificação com o candomblé envolvem tanto uma relação da pessoa consigo mesma, quanto com o grupo de culto e com as divindades e que a análise deve levar em conta os aspectos reflexivos e pré-reflexivos envolvidos nas interações concretas, sobre os quais emerge toda reflexão. Este capítulo procura explorar exatamente como o não refletido pode ser 
envolvido numa análise do processo de tornar-se um membro de um terreiro de candomblé.

Várias vezes destaquei que a abertura inerente à autoidentificação com a religião não se cristaliza completamente num dado momento, sendo um processo contínuo. Certos eventos ou características - pessoais, do grupo religioso, da experiência escolar ou profissional - são tematizados num dado momento, operando como espécies de núcleos ao redor dos quais as narrativas são construídas. Contudo, estas não podem ser assimiladas à identidade pessoal, ao senso que a pessoa tem de si mesma, o qual sempre vai muito além das narrativas que produz. O processo em seu desenrolar não perde sua flexibilidade e mesmo o passado pessoal pode ser ressignificado de formas um pouco diferentes, com tons diversos, quando é chamado a fazer sentido, isto é, retomado a partir do presente e é, assim, envolvido no projeto de futuro, seja a tarefa imediata a que o sujeito se lança, seja um futuro somente imaginado. (JENKINS, 2002; LAMARQUE, 2004, p. 405)

Esta flexibilidade da prática humana, porém, não é desprovida de toda estruturação, pois esta é regida por esquemas encarnados (embodied) de avaliação e percepção que estão assentados sobre a constituição fundamentalmente sociocultural do mundo da vida. (CSORDAS, 2002) A cristalização das avaliações e percepções em esquemas corporais nos fala de como o corpo do sujeito (ou do agente social) é irremediavelmente construído por e construtor de distinções culturais, frisando, assim, a impossibilidade de objetos puramente naturais na experiência. Acima e abaixo, por exemplo, não são apenas posições no espaço objetivo - mensurável, abstrato e empiricamente dado - mas antes, são simultaneamente posições relativas ao meu corpo que se move, que alcança ou não um dado lugar e carregadas de valores. Olhar alguém de cima para baixo é uma forma de expressão corporal cujo sentido é bem conhecido em nossa sociedade. 
No primeiro capítulo foi discutida a importância da educação e da escolarização na formação de tais esquemas para profissionais de classe média e como elas constituem um eixo de corte entre "nós" e "outros". Agora a questão é tratar de como a convivência no candomblé aparece para esse habitus escolar, já que ele parece permanecer como a base incorporada que condiciona a aproximação com a própria religião.

\section{HABITUS E EMBODIMENT}

Segundo Csordas (1994, p. 8), Merleau-Ponty buscou tratar dos processos encarnados (embodied) de percepção nos quais a experiência de estar no mundo tem seus "inícios", ao invés de se limitar aos objetos da cultura já constituídos, onde a percepção "termina”. Para tal propôs o conceito de pré-reflexivo ou pré-objetivo. Conceitos, ideias e representações são objetos culturais e não a base da experiência vivida. São resultados da tematização desta experiência, de sua retomada num esforço reflexivo, são formas de objetivação. Embora os objetos da reflexão constituam parcela importante da vida pessoal, é preciso considerar também a maneira como os sujeitos estão imersos junto com outros em um mundo dado, seus modos de engajamento prático neste mundo que, na maior parte das vezes, não exige o recurso à reflexividade, à tematização produtora de objetos. É importante ter em mente que o conceito de pré-objetivo em nenhum momento afasta a ação humana de sua fundamentação cultural. Apenas aponta para modos de envolvimento no mundo e com os outros que antecedem à reflexão e a partir dos quais esta emerge. Estamos imersos num mundo que, sendo humano, é desde sempre carregado de sentidos.

Ainda segundo Csordas (1994), a tematização isolada não dá conta da emergência dos objetos culturais e nem do outro para mim. É preciso refinar a análise com uma teoria sobre a prática, na qual estes dois pontos sejam mantidos como complementares: 
Acabamos de ver que o objetivo de Merleau-Ponty é transpor o estudo da percepção de seus objetos para os processos de objetivação. Paralelamente, o alvo de Bourdieu para uma teoria da prática é mover-se para além da análise dos fatos sociais como opus operatum para uma análise do modus operandi da vida social. Ele encontra este modus operandi no conceito de habitus, definido como um sistema de disposições duráveis. Este sistema constitui o princípio inconsciente, coletivamente inculcado para a geração e a estruturação tanto de práticas quanto de representações. (CSORDAS, 1994, p. 9, grifo nosso, tradução nossa)

Apesar das aproximações há diferenças importantes entre os dois autores. Se Merleau-Ponty acaba por dar mais margem à fluidez, à indeterminação na relação do sujeito com o objeto, Bourdieu (2003) ${ }^{92}$ termina por acentuar a determinação do próprio sujeito. É muito mais fácil ver a face estruturada do habitus operando nas práticas dos agentes, ou sua face estruturante como reprodutora, do que sua qualidade generativa. Embora o autor admita a modificação do habitus ao longo da vida e a aquisição de novos elementos, é muito mais claro como os princípios de estruturação são capazes de posicionar qualquer objeto - ou agente, ou grupo desses - por sua capacidade de aplicação aos campos mais diversos da vida social, do que como são constituídos na e pela prática. E toda possível mudança deve ser reportada a uma alteração no estado das relações de força num campo dado - que tornam habitus consolidados inadequados - ou à trajetória de um indivíduo por posições distintas em tais campos, por exemplo, a idade que transforma um "adulto maduro" em "velho", situando-o de maneira diferente nas relações de produção econômica. É exatamente este movimento que McNay (1999, p. 110-113) faz ao utilizar o conceito de habitus em seu potencial transformador. Como o habitus só se realiza em um campo da prática e cada um destes segue uma lógica relativamente autônoma (exacerbada nas condições contemporâneas), surgem inadequações entre habitus e relações

92 Ver, por exemplo, Bourdieu (2003, p. 101; 1999b). 
estruturais do campo quando consideramos que os agentes não vivem confinados a apenas um deles em sua vida cotidiana. Assim, é o próprio conflito entre as diferentes disposições exigidas às mulheres na vida doméstica, no mercado de trabalho e na intimidade, por exemplo, o que traz um potencial libertador à identidade feminina e não um suposto incremento da reflexividade dos sujeitos na contemporaneidade.

Este tipo de formulação exige um grande cuidado para que o sentido das práticas humanas não seja procurado além delas, já que podem aparecer apenas como encarnações de uma lógica que seria a verdadeira chave para a compreensão dos sentidos que os sujeitos empíricos acreditam existir em suas ações. Mesmo as mudanças nos possíveis sentidos da prática poderiam ser reportadas ao conflito entre lógicas distintas. Deste ponto de vista, o problema é semelhante ao da significação na experiência - isto é, de onde provém o sentido da ação humana. No entanto, para Bourdieu, a prática não tem lugar num mundo caótico, organizado desde fora. Ela mesma é organizadora deste mundo, expressando princípios que se encontram inscritos em lugares e corpos. Dessa forma, toda ação tem sempre sentido, inclusive mais do que os indivíduos podem se dar conta na reflexão. (CSORDAS, 1994, p. 12)

A crítica que Budgeon (2003) dirigiu à Giddens pode ser, então, confrontada à posição de Bourdieu. Como já vimos, para a autora, a ênfase de Giddens na inscrição da cultura sobre os corpos - isto é, como eles podem ser tomados como objeto da prática reflexiva - acaba por apresentar sujeitos desencarnados, embora mantenha sua agência. É importante comparar esta crítica com as proposições de Bourdieu porque ao se acentuar demais a organização social das práticas e valores - sua hierarquia inscrita nos corpos e espaços - e tentar manter uma concepção de agência corre-se o risco do ressurgimento de uma dicotomia. De um lado haveria sujeitos encarnados empíricos, situados, posicionados socialmente. De outro lado, classes de agentes, também socialmente situados. Sobre os primeiros re- 
cairia toda a inscrição que os situa até mesmo naquilo que parece ser o mais biológico (seus gostos, gestos, movimentos) e aos segundos estaria reservada a agência obedecendo a uma lógica própria, interna ao par inclusão/exclusão referente a um campo, a uma dada situação de forças entre diferentes classes de agentes que competem para acumular o capital específico àquela esfera. ${ }^{93}$

Para Csordas, a questão recai no estatuto atribuído por cada um dos autores à indeterminação. Em Merleau-Ponty é a própria percepção que nunca esgota o objeto - mantendo sempre a possibilidade de outros pontos de vista -, enquanto que em Bourdieu (1994, p. 11) trata-se de uma indeterminação lógica, exatamente a que permite a aplicação dos mesmos esquemas de avaliação e percepção aos campos mais diversos e dá conta da variação na vida cotidiana. Portanto, diferentemente da crítica normalmente feita a Bourdieu, o problema de suas proposições não estaria na sobredeterminação econômica do sujeito, mas numa certa autonomização da lógica estrutural: são as diferentes lógicas dos distintos campos, que exigem disposições diversas e, entrando em conflito, oferecem uma certa indeterminação à prática. É preciso cuidado com esta ênfase, pois chega-se perigosamente perto de um sujeito desencarnado e é preciso ater-se ao aspecto produtivo do habitus incorporado para evitar este risco.

Já em Merleau-Ponty a plasticidade é inerente à condição encarnada dos sujeitos, pois a percepção mesma não nos dá objetos

93 É possível questionar ainda a redução de toda lógica de qualquer campo à acumulação de seu capital específico e à operações binárias. No caso do campo religioso pode-se argumentar que há lógicas distintas operando a depender do eixo de corte do campo, por exemplo, todas as instituições religiosas do campo soteropolitano estariam em disputa pelo mesmo capital simbólico. Na esfera do candomblé propriamente dito, os terreiros estariam operando na lógica da acumulação e monopólio do capital religioso, mas dentro de um mesmo terreiro não é frutífero distinguir estritamente entre "produtores" e "consumidores", ou "dominantes" e "dominados". A lógica da dádiva, da acumulação para distribuição, proposta por Mauss (2003b), Caillé (1998) e Bourdieu (1996) parece mais adequada para as análises no interior do grupo. Pode-se contestar que num grupo empírico encontram-se indivíduos com posições diversas em distintos campos (religioso, produção econômica, relações de gênero etc.) e que isto faz com a lógica da acumulação não seja evidente, mas não seria, então, justamente o caso de se pensar numa lógica mais inclusiva, acumulação mais redistribuição, por exemplo? 
- que são produtos secundários do pensamento -, mas facetas, perfis, conclamando a atividade da consciência à “completá-los”, retirá - los da indeterminação. Contudo, pelo próprio fato de ser uma consciência encarnada, situada no mundo com outros - e não uma razão universal, uma faculdade humana, ou qualquer operação de reflexão desencarnada - sua tarefa tem lugar num mundo intersubjetivo e, necessariamente a partir de um ponto de vista nele situado. ${ }^{94}$ Isto quer dizer que esta atividade se dá sempre num horizonte de sentidos culturalmente constituídos. O sujeito encarnado tem os limites de sua percepção e atividade reflexiva no seu entorno já constituído por e com outros, em suma, num mundo intersubjetivo e é a ele que se deve reportar a inteligibilidade das ações. Com isto também se coloca a questão da ininteligibilidade: maiores são as dificuldades quanto mais distantes forem os horizontes culturais da experiência. Por outro lado, da mesma maneira que nenhuma percepção esgota o objeto - ou seja, a transparência nunca é total - tampouco há uma impossibilidade radical de compreensão - e a opacidade nunca é completa. Isto pressuporia um objeto em si acabado ao qual a cognição se lançaria.

Embora os conceitos propostos por Merleau-Ponty enfatizem a natureza cultural do mundo humano, sua formulação pode parecer universalista por demais. Este é o teor da crítica que Weiss (1999) dirigiu ao filósofo, sem discordar do alcance de suas análises. Para acentuar a especificidade de ser um sujeito encarnado no feminino numa dada sociedade (norte-americana contemporânea) a autora propôs um desenvolvimento pormenorizado da noção de imagem corporal, já presente nas discussões do primeiro. Segundo Weiss, a imagem corporal fornece um senso de unidade ao sujeito - que tem e é um

94 Percebe-se aqui uma diferença crucial entre Merleau-Ponty (1962) e Bourdieu (2001). Enquanto que para o segundo é a homologia estrutural entre campos de prática que permite a "leitura" pré-reflexiva de quem é o outro, em Merleau-Ponty é o compartilhamento de sentidos num horizonte de indeterminação que atinge vários níveis, desde o orgânico - no qual o outro tem um corpo como eu - até os objetos culturais propriamente ditos - um certo tom de voz "significa" raiva, por exemplo. 
corpo dotado de uma certa integridade esquemática. Esta se desenvolve a partir dos investimentos afetivos diferenciados em partes ou capacidades do corpo. Assim, diferentes cores de pele recebem investimentos diversos, culturalmente determinados. Da mesma maneira, os sexos. Também os membros, órgãos e funções não são igualmente investidos, por exemplo, a cabeça e as nádegas, ou a fala e a excreção têm pesos diferenciados. Os valores da sociedade não são apostos aos corpos, como avaliações exteriores, mas participam do próprio senso de unidade corporal que sustenta os limites do sujeito. Não se trata apenas de uma exploração das maneiras como culturas são inscritas nos corpos, mas de formas de estar no mundo. A imagem corporal é muito menos uma imagem de si do que uma sistematização das relações intersubjetivamente constituídas com corpos e seus "atributos". Ela esquematiza modos de se voltar para o mundo, para si próprio e para o outro. Sendo indeterminada, isto é, um processo contínuo que não se fecha totalmente ao redor de um atributo ${ }^{95}$ ou conjunto deles, a imagem corporal pode vir a abarcar novos gestos, novos valores, novas potencialidades e incapacidades. Dessa maneira, é uma verdadeira identidade corporal. Como sustentou Jenkins (2002) a existência encarnada fornece um senso de continuidade ao sujeito e ao mundo e, simultaneamente, a base sobre a qual são vividas as transformações.

A noção proposta por Weiss (1999) para caracterizar o senso de integridade subjacente à corporalidade é extremamente próxima a de arco intencional, utilizada por Merleau-Ponty para expressar a unidade nunca dada de antemão do sujeito da percepção:

Protanto, deixem-nos dizer, emprestando um termo de outros trabalhos, que a vida da consciência - vida cognitiva, vida do desejo ou vida perceptiva - é antes subtendida por um 'arco intencional' que projeta em torno de nós nosso passado, nosso futuro, nosso ambiente humano, nossa situação física, ideológica e moral, ou ainda, que resulta do fato de estarmos

95 A rigidificação da imagem corporal em torno de um atributo - por exemplo, a massa corporal - ou um momento da vida, pode mesmo trazer transtornos que se manifestam no que foi chamado de psicopatologias, segundo Weiss (1999). 
situados a todos esses respeitos. É este arco intencional que coloca a unidade dos sentidos, da inteligência, da sensibilidade e da motilidade. (MERLEAU-PONTY, 1962, p. 136)

Esta noção de arco intencional apresenta também o caráter unificador e situado do habitus. Ela também diz respeito à integração de valorações - investimentos afetivos - e práticas distintas num senso de unidade que é o ponto de vista do sujeito encarnado. Mais ainda, diz respeito à capacidade de executar gestos sem que seja necessária uma reflexão acerca das partes do corpo envolvidas, sem correr o risco de sugerir uma "figura mental" de si mesmo, o que ocorre com a noção de imagem corporal. A única vantagem apresentada por esta última é a clareza de exposição quando é necessário enfatizar a incorporação de possibilidades culturais. Assim, toda vez que o termo for utilizado na análise a seguir deverá ser compreendido como uma referência ao arco intencional tal como proposto por Merleau-Ponty (1962).

Se a própria noção de embodiment expressa tanto indeterminação quanto integração e situação, qual seria, então, a necessidade de manter na análise o conceito de habitus se ele realmente ameaça introduzir um mal entendido? Como argumentou Csordas (1994), o conceito permite explorar a especificidade cultural que se encontra pressuposta nas análises de Merleau-Ponty, ou melhor, implicada na noção de intersubjetividade ${ }^{96}$ e manter seu embasamento encarnado, isto é, sem remeter a compreensão e o sentido para uma suposta "camada" reflexiva dos sujeitos, responsável pela significação a posteriori de suas experiências. O habitus possibilita explorar as especificidades de esquemas corporais sem recorrer à noção de "imagem”, criticada acima. Mais ainda, com sua referência necessária ao campo, o habitus permite uma aproximação à especificidade no interior de um mesmo grupo, permite que se considere que há sempre alguma

96 É preciso atentar para o fato de que este conceito não significa a interpenetração de subjetividades isoladas, mas sim uma espécie de tecido de padrões de comportamento que têm lugar no que é chamado de mundo objetivo e vida subjetiva num único e mesmo movimento que, ademais, nunca estanca. (CSORDAS, 1994, p. 12-13) 
compreensão da prática alheia sem que isto implique num suposto compartilhar de representações. O que veremos a seguir é exatamente isto: não é por pertencer a um mesmo terreiro que as pessoas passam a compartilhar, automaticamente, valores, julgamentos ou apreciações. Em outros termos, podemos dizer que o candomblé oferece elementos para distintos estilos de vida, mas não que fornece um único estilo de vida a seus membros.

Evidentemente, nem todos os conflitos e inadequações que emergem nas interações no terreiro podem ser referidos à uma posição específica da classe, escolhida como objeto desta análise. Alguns deles dizem respeito muito mais ao gênero e à idade:

Quem é nova e tem tudo duro que ache que pode mostrar seus peitos a todo o mundo, eu que sou velha é que não vou ficar mostrando tudo por aí.

Estes foram aproximadamente os termos nos quais uma iaô de cerca de 50 anos se queixou do fato de ter que trocar de roupa no mesmo quarto em que os homens o faziam. O fato das filhas de santo mais novas se trocarem sem incômodo num ambiente misto aparecia-lhe claramente como uma impropriedade, algo que "não cai bem" e que ela "não podia fazer". Em duas ocasiões que presenciei no Torrundê, as mulheres mais velhas tentaram tomar posse de um quarto com banheiro só para elas. Na primeira, a tentativa foi frustrada pelas condições físicas em que se encontrava o local: a fiação elétrica não estava boa e as lâmpadas não acendiam, com isto era impossível fechar a porta que, além do mais, estava sem trinco. Na outra, pai Dary havia acabado de construir um novo quarto com banheiro e uma das filhas mais velhas conseguiu o privilégio das chaves. Nas primeiras sessões e festas ela, manteve o controle do acesso ao espaço, admitindo as mais velhas e equedes, é claro, bem como as mais novas e abiãs que eram do seu agrado. No entanto, poucos meses se passaram até que alguns filhos de santo contornassem suas restrições, dando início novamente ao desconforto das mulheres de mais idade. 
No terreiro são frequentes as queixas de abiãs, e mesmo de alguns iaôs, que se julgam vítimas da jocosidade de outros por não saberem dançar bonito, tomar a bênção direito e outros gestos que passam a funcionar como demarcadores entre os "realmente de dentro" e os novatos. Evidentemente nem só os filhos da classe média são vítimas de tais comentários, mas o são preferencialmente, já que não foram - à exceção de Paulo - familiarizados com o candomblé desde a infância e os períodos iniciais na roça envolvem todo um aprendizado gestual para eles. No entanto, embora os adeptos não considerados diretamente neste estudo não constituam um grupo homogêneo e harmonioso (muito ao contrário, como mostram as queixas e brigas frequentes), parecem também ter alguma percepção da distinção que os separa dos primeiros. Um exemplo pode ser visto na diferenciação entre os que ingressam no candomblé por "necessidade" e aqueles que "acham bonito". Frequentemente, pude ouvir entre os filhos de santo de classe popular a censura aos que pensam que a religião é "só para mostrar a saia na roda”, o que pode ser uma alusão direta tanto à qualidade das roupas confeccionas por aqueles com mais recursos financeiros, quanto à ênfase que estes colocam (nos casos aqui estudados) na ideia de que a religião é uma “opção” individual. Eu mesma recebi esta crítica, algumas vezes, por ser uma pessoa que se tornava relativamente próxima sem me tornar, efetivamente, filha de santo.

Em suma, gostaria de sugerir que à flexibilidade inerente às formas de embodiment, o esquematismo corporal do habitus acrescenta uma ênfase em seu caráter integrador. Enquanto que as primeiras nos falam de como corpo e consciência são vividos como uma unidade, tanto no que diz respeito à união inextrincável de ambos na experiência, quanto à solidariedade dos sentidos (MERLEAU-PONTY, 1962, p. 116-120), o segundo expressa uma percepção de conjunto entre elementos tão heterogêneos como vestuário, alimentação, ocupação, tratamento socialmente adequado, posturas valorizadas, entre inúmeros exemplos, formando aquilo a que chamamos estilo de vida. Estes dois conceitos, por manterem a ambiguidade entre determina- 
ção e inovação, nos permitem compreender como o candomblé passa a fazer parte do mundo desses profissionais de classe média, e viceversa, ou como se dá a integração desta religião na vida destas pessoas, sem ignorar os conflitos e as dificuldades que emergem na frequência ao terreiro. Passar a ser de candomblé significa abrir-se para uma série de possibilidades, desde a convivência com pessoas de origem sociocultural muito heterogênea até a incorporação das entidades. Esta abertura só pode ocorrer a partir do enraizamento do sujeito em seu mundo, carregado de clivagens, sobre o qual se estende o arco intencional que sustenta a integração da religião que se escolheu num estilo de vida e num modo de ser. Enquanto as percepções e avaliações que a religião requer não forem incorporadas, muitas situações emergirão como tarefas difíceis ou como conflituosas durante as interações concretas.

\section{INDUMENTÁRIA, CONVIVÊNCIA E HIERARQUIA}

Anteriormente, indiquei que as pessoas acompanhadas nesta pesquisa carregam um habitus escolar - e que sua posição de classe se expressa especialmente numa distinção calcada na "educação" e na "cultura" - que fornece parâmetros para a maneira como elas interagem com outros e os percebem. Suas formas de compreensão da religião e de si mesmos também se apresentam perpassadas por esta matriz, embora em diferentes graus para indivíduos com idades distintas e diversos períodos de engajamento na religião. Assim, para analisar como se dá o processo de identificação com o terreiro de candomblé convém atentar para as inadequações, as dificuldades e impropriedades que surgem nas interações concretas.

A hierarquia religiosa de um terreiro de candomblé se expressa de diversas maneiras práticas. Uma das mais evidentes - quando nos familiarizamos com o código - é o vestuário nas obrigações. Quem 
pode dançar de sapatos, quem pode usar bata ao invés de camisu, ${ }^{97}$ quem pode usar pano da costa, são detalhes que indicam o grau iniciático de cada membro da roça. (BAPTISTA, 2009) Apenas ebomis têm o direito a ostentar tais objetos. Na verdade, há uma série enorme de variações de vestuário que permite inferir a posição de cada um, indo desde estes elementos mais óbvios até o tipo e a espessura do colar de contas que pode ser utilizado. Mais uma vez, há variações entre terreiros de diferentes linhagens, mas algumas regras parecem ser quase um consenso e no Torrundê tive a oportunidade de observar o trabalho dos mais velhos para que os mais novos "permaneçam em seu lugar”. Pai Dary, que é bastante paciente e dado a explicar aos filhos os motivos das exigências, disse uma vez a um grupo de adeptos que, se uma abiã ou uma iaô usarem as roupas dos mais velhos, não serão capazes de sentir a importância da passagem ritual de um status a outro. Seus termos foram mais ou menos os seguintes:

Que importância vai ter pra você quando eu, no meio do barracão, te entregar a bata e disser, 'minha filha, você não usa mais blusa de crioula', se nesses anos todos você já vestiu bata e pano da costa?

Como no Torrundê as obrigações contemplam um, três, cinco e sete anos de iniciação, há distinções de vestuário para cada etapa e recentemente tem havido um esforço mais claro para manter a obediência às regras. Para dirimir dúvidas, o babalorixá havia fixado duas páginas impressas com as normas de conduta e vestimenta, ao lado da porta da cozinha. Nelas podíamos ler que abiãs devem vestir exclusivamente roupas brancas "simples" - isto é, saia sem goma, blusa branca, atacã e ojá simples, para as mulheres e calça de ração com blusa branca para os homens - com apenas o fio de contas de seu orixá, quando já lavado. Iaôs mulheres devem vestir saia com anágua,

97 Um tipo de blusa longa e reta, com decote arredondado e mangas curtas, de algodão, mas que pode ter uma série de enfeites, como bordados, bicos e rendas. Deve ter "fralda", isto é, deve chegar até a altura dos joelhos, com aberturas laterais abaixo dos quadris que facilitam os movimentos. 
atacã, camisu, pano da costa acima da cintura e ojá - que podem ser bordados e enfeitados. Os homens usam uma espécie de bata masculina amarrada sobre um ombro que vai até a altura das coxas e calças parecidas com as dos abiãs, porém de melhor qualidade e mais enfeitadas. Além disso, devem portar os colares referentes à iniciação, os diloguns (longos e grossos, compostos por 16 fios de contas unidos por uma espécie de conta maior, as firmas, a intervalos regulares), além dos contra-eguns e mocãs, feitos de palha da costa trançada. Devem dançar descalços ${ }^{98}$ e não podem usar batas rendadas. Já os homens ebomis podem usar chinelos, um tipo de bata com mangas e um tipo de barrete do mesmo tecido da roupa. As ebomis devem se vestir com a indumentária completa que inclui algumas anáguas, bata rendada e o pano da costa na cintura, além das sandálias e chinelos de salto (evidentemente, a preferência é por modelos fáceis de descalçar, o que terá que ser feito caso o orixá desça). Outro elemento já mencionado são os colares diferenciados que podem ser utilizados e, em geral, já não são feitos de miçangas, mas de contas de cerâmica em formatos, tamanhos e cores variados, ou mesmo de outros materiais como chifre de bois e búfalos. Desse ponto de vista, podemos dizer que a hierarquia encontra-se inscrita no vestuário e sobreposta aos corpos dos iniciados.

Isto diz respeito aos momentos de execução pública dos rituais. Já aí há a questão de se executar todos os movimentos sob tantas camadas de tecido. ${ }^{99}$ Durante todo o tempo que se está presente no terreiro, preparando as cerimônias ou arrumando tudo depois, não se usa roupas “civis” (exceto durantes os trabalhos de reforma, cons-

98 Após o bori, os abiãs devem usar também um fio simples branco de Oxalá. Na obrigaçãa de cinco anos os iaôs ganham o direito de usar chinelos, mas totalmente sem salto, o que é prerrogativa das ebomis. Estas duas distinções não estão impressas, mas são efetivas, servindo de diferenciação interna a cada grupo de membros do terreiro ou causando confusão quando são desconsideradas.

99 Apenas como curiosidade: no primeiro semestre de 2003, em Cleveland, Ohio, EUA, conheci uma Iyanifá (sacerdotisa de Ifá) iniciada em Oyó, Nigéria, que já havia estado em Salvador. Ela comentou comigo, em tom recriminatório, que não sabia como os orixás daqui podiam dançar "amarrados" em tantos panos. 
trução ou escultura, quando todos os envolvidos usam trajes confortáveis e que serão praticamente destruídos pelo contato com materiais como cimento, cal, tintas etc.). Mencionei acima as regras de conduta também afixadas junto à cozinha. Nelas constava que qualquer membro do terreiro deve, logo ao chegar, tomar um banho, vestir-se adequadamente e ir tomar a bênção aos mais velhos. Isto significa vestir as "roupas de ração", blusas ou camisetas, em geral brancas com calças largas ou saias simples de algodão resistente, branco ou estampado. As saias de ração não são diferentes daquelas menos elaboradas, usadas nas sessões de caboclo, ou pelas abiãs o tempo todo. ${ }^{100}$ Com esta vestimenta serão realizadas todas as tarefas. Talvez para os homens isso não represente muita diferença do modo cotidiano de se vestir, já que suas roupas são leves e eles usam calças, mas para as mulheres, significa ter que varrer, lavar panelas imensas, fazer comida, tratar a carne de animais, sentar, agachar, levantar, usando saias amplas que muitas vezes entram no caminho. Pode ser esta a razão do hábito de se amarrá-las acima do busto ou sobre um dos ombros, prendendo a cintura com um ojá, da maneira como os caboclos fazem quando tomam os corpos de suas filhas nas sessões. Dessa forma as saias ficam pela altura dos joelhos, não chegando aos tornozelos, mas mesmo assim, ainda comportam uma boa quantidade de tecido que, muitas vezes, é segurada no meio das pernas de modo a não atrapalhar. É claro que isto só é possível quando a atividade exige mais movimentos das mãos e braços. As mulheres mais velhas não costumam vestir suas saias dessa maneira e sim normalmente, na cintura. Prendem, então, algumas partes da barra no cós, diminuindo a movimentação do tecido.

De toda forma, temos aqui uma situação na qual o vestuário dos rituais públicos evidencia a inscrição da hierarquia sobre os corpos dos membros do terreiro, ao passo que as vestimentas de trabalho

\footnotetext{
100 É importante ressaltar que o "simples" no candomblé significa apenas "um pouco menos elaborado", sendo bastante bem cuidado e até mesmo as roupas de ração podem ostentar bordados e outros "enfeites".
} 
evidenciam uma forma de requisitar o corpo, certas exigências de movimentação. Nas roupas das festas podemos ver a demarcação de proximidades e distâncias nos termos hierárquicos da própria religião. Nas roupas de ração uma demarcação de distância com relação às atividades cotidianas. Passar a ser de candomblé significa, entre muitas coisas, mover-se com naturalidade em trajes não costumeiros para a maioria de nós em Salvador. As tarefas executadas também não fazem parte do cotidiano usual de uma grande cidade, mas serão objeto da próxima sessão. Por enquanto é interessante ter em mente que tais indumentárias de trabalho constituem o primeiro conjunto de vestuário que um abiã irá providenciar. Assim, logo no início de sua aproximação com o terreiro ele - sobretudo ela - terá que se vestir de certa maneira e apropriar-se de um modo de se mover e, como argumentou Merleau-Ponty (1962, p. 106):

Nunca movemos nosso corpo objetivo, mas sim nosso corpo fenomênico e não há qualquer mistério nisso, uma vez que nosso corpo, como potencialidade desta ou daquela parte do mundo, é o que se levanta em direção aos objetos a serem apanhados e os percebe.

Assim, ao colocar exigências aos modos de movimentação de seus membros, o candomblé está estabelecendo os limites de seu mundo. Ao reivindicar formas de movimentos antes não usuais, podemos dizer que a religião está forçando tais limites para além daqueles já incorporados em seu habitus. Em resumo, isto é o que será apresentado durante todo este capítulo, porém, sob vários aspectos. Por ora, retornemos às interações no terreiro, pois é através delas que podemos observar tais exigências.

A hierarquia do terreiro, no entanto, não se limita à expressão nos suportes materiais de roupas, cadeiras e posições - posição física - no barracão. Ela é também praticada em uma série de gestos, como tomar a bênção e ocupar o lugar certo na roda. Os mais novos devem, idealmente, descalçar-se e deitar aos pés da pessoa a quem pedem bênção. Há ainda uma diferenciação a depender do sexo do orixá de 
cabeça: os que têm orixás masculinos deitam-se de frente, com o corpo reto; os que têm orixás femininos deitam-se apoiando primeiro um lado do corpo, deitando-se completamente depois e girando os quadris de um lado para o outro. Ao se tornar ebomi a pessoa não precisará mais se deitar. Apenas se curvará um pouco, estendendo as mãos na direção daquele que dará a bênção. ${ }^{101}$ Os mais novos devem sempre tomar a iniciativa do pedido, mesmo quando o status de ambos é igual, cabendo ao mais velho abençoar primeiro para só depois devolver a solicitação. Isto tudo compõe um quadro ideal. Na prática, na correria da cerimônia pública iminente, os próprios mais velhos impedem que abiãs e iaôs deitem-se no chão, bastando a menção de fazê-lo para que sejam abençoados. O gesto, mesmo interrompido em seu início, não perde seu valor e é reconhecido como uma adequação da atitude da pessoa às exigências da hierarquia religiosa. Muitas vezes, porém, as pessoas pedem a benção àquelas com quem têm mais afinidade e não a todos os seus mais velhos, abrindo mais uma possibilidade de conflito.

Mais uma vez, a situação descrita não diz respeito exclusivamente aos profissionais de classe média e sim a qualquer pessoa que não tenha crescido no ambiente do candomblé. Entretanto é especialmente apta a entrar em choque com sua posição socioeconômica. A maioria das pessoas que entrevistei expressou uma valoração positiva da obediência a tais normas, mesmo que esta tenha vindo com o tempo. É o caso de pai Robson, para quem o candomblé foi "um exercício de humildade". Sua família, porém não compartilhava dessa opinião:

Chegou ao ponto do meu pai nunca ter ido no candomblé me ver, porque não admitia. Ele dizia, 'eu te criei, eu te eduquei, você nunca... você quando quer dar a benção você dá e quando não, você passa por mim é 'bom dia'. Pra te ver deitar nos pés de um homem pra que ele te abençoe'?!

${ }^{101}$ No Torrundê o gesto de beijar a mão do outro e deixar a sua ser beijada depois não é habitual, embora eu tenha observado esta forma de troca de bênçãos em muitos outros terreiros de Salvador. 
A emergência de conflitos em torno dessa questão depende muito de idiossincrasias, pois alguns mais velhos não se importam tanto enquanto que para outros é uma ofensa grave que os mais novos não lhes demonstrem esse sinal de respeito. Da mesma forma, alguns dos mais novos se esforçam para não cometer a gafe, ao passo que outros são mais relaxados. Nem por isso a expressão do respeito pela hierarquia através dessa atitude perde a importância para os membros do terreiro. Já ouvi algumas vezes a menção a Fábio como um filho de santo exemplar e em uma delas (na sua obrigação de sete anos) seu comportamento para com os mais velhos e os orixás foi referido como modelo a ser seguido.

No extremo oposto, mais uma vez, o caso de Rosana é interessante. Já mencionei que um de seus maiores problemas de adaptação ao terreiro foi com relação a tomar a bênção. Ela se recusava terminantemente a fazê-lo para qualquer outra pessoa que não fosse pai Dary. Não achava adequado ter que se "deitar" para outras pessoas. No terreiro em que ela havia iniciado um tratamento espiritual, antes de conhecer o Torrundê, houve também o mesmo conflito:

Aí, depois ela [a mãe de santo] disse que ia fazer um negócio de noite e que eu tinha que dar a bênção. E me ensinou que eu tinha que dar a bênção, como é o nome? Que eu tinha que beijar os pés. Ai eu disse, ai foi que pegou o negócio. [risos] Eu saí, não voltei mais.

Já foi dito que Rosana considerava pai Dary "uma pessoa como nós” e tinha confiança nele. Talvez por isso não se importasse em lhe tomar a bênção. As tensões em torno da hierarquia foram, anteriormente, analisadas em relação à sua fundamentação e às expectativas de legitimidade por parte dos adeptos de classe média. Agora, vemos outro aspecto da mesma questão. Isto evidencia que as perspectivas analíticas não esgotam qualquer objeto e que é sempre possível retomá-los e fazer emergir sentidos a depender do ponto de vista. Uma interpretação não elimina as outras, mas procurando agregar formas distintas de abordar um mesmo tema, podemos en- 
contrar maneiras de enunciar vários sentidos que se conjugam na prática. Por ora, o que desejo acentuar é que valor e gesto são inseparáveis.

Nas vezes em que Rosana pediu minha opinião e a aconselhei a cumprir a regra, lhe perguntei o porquê de sua dificuldade. Ela não sabia responder com clareza, dizia que não gostava, que não tinha idade para isso. Era algo que não lhe caía bem. Tomar a bênção é um ato de prostrar-se frente à outra pessoa, descer ao nível de seus pés. Era dessa forma que Rosana compreendia um ato que pode ser sentido de maneira completamente diferente: como um colocar-se sob a proteção de alguém com maior poder espiritual. Na verdade, ela não gostava de executar nenhum gesto que incluísse agachar ou deitar-se. É preciso ponderar também que Rosana já se aproximava dos 50 anos de idade, o que, provavelmente, acrescentava uma dificuldade "orgânica” à execução de tais gestos. Isto, porém, não era apenas "dado", sendo constantemente retomado por ela como justificativa, o que evidencia a profunda imbricação entre o "físico" e o "valorativo". Sua existência corporal como uma mulher de uma certa idade era frequentemente tematizada, colocando uma dificuldade adicional ao seu engajamento nos gestos exigidos. Em seu caso, os esquemas de avaliação já incorporados falaram mais alto do que sua relação ainda inicial com o grupo de culto e geraram uma série de conflitos e antipatias que culminaram com seu afastamento sob a pecha de "maluca". Até comigo ela rompeu relações, passando mais de um mês sem me dirigir a palavra, devido à minha insistência para que ela tentasse se adequar às regras do terreiro, talvez, somada ao fato de minha lenta aproximação com a Iá Morô, uma das pessoas com quem ela entrava em confronto mais direto. O que julgo mais interessante neste caso, contudo, é o modo como Rosana tematizou um gesto valorizado no interior do grupo de culto (deitar-se para tomar a benção) como uma dificuldade praticamente insuperável.

Ao contrário do que me disseram Hortência e Ernesto, o terreiro não vive em tensão como qualquer lugar onde se junte muita gente. 
O terreiro não é um lugar como outro qualquer, suas regras e exigências são específicas e os conflitos que emergem giram em torno delas. Como ele mesmo disse, é difícil aprender o seu lugar, "na frente de quem" não se pode passar. Há muitas outras normas envolvidas nesta questão da hierarquia, por exemplo, quem pode ser chamado pelo nome ou apelido e quem deve ser chamado pelo cargo. Mais do que um conjunto de representações acerca do status de cada um, é preciso aprender a se "situar". O "lugar" que se ocupa requer um modo de se dirigir aos outros. No caso dos profissionais de classe média, esse modo muitas vezes significa uma inversão das posturas do cotidiano, ou mesmo das relações de poder entre pessoas de origem social diferente (SILVA, 1998, p. 86-87), quando é o caso de uma professora universitária, ou um médico se deitar para ser abençoado pela diarista. Em outras situações, trata-se de um conflito entre o que é tido como a maneira adequada de se tratar alguém com quem se tem um vínculo afetivo (saudar alegremente, abraçar e beijar no rosto) e a maneira adequada de se tratar alguém no candomblé, que exige o cumprimento de certas normas quanto ao corpo (tomar banho e vestir-se com as roupas de ração) e quanto aos gestos (colocar-se abaixo da outra pessoa, deitando-se ou curvando-se, e pedir-lhe a bênção).

Este, porém, é apenas um primeiro ponto de aproximação à questão. A presença no terreiro exige muito mais do que vestir certas roupas e respeitar uma hierarquia.

\section{LIMPAR GALINHAS E OUTROS GESTOS DIFÍCEIS}

No capítulo anterior reiterei que a autoidentificação com o candomblé deve ser pensada com relação às tarefas executadas e às relações com pessoas concretas, e não apenas como um movimento reflexivo do sujeito. Já vimos que a inserção dessas pessoas na comunidade de culto é sobremaneira marcada pela emergência de vários conflitos e especialmente no que diz respeito às atividades de preparação das cerimônias. Este é um âmbito de atividade privilegiado para se pensar a autoidentificação como processo encarnado, pois exige - 
e evidencia - exatamente a presença corporal dos sujeitos na roça. Da parte dos filhos de santo, ogãs e equedes mais disponíveis para as atividades religiosas, o modo de agir dos membros de classe média é muitas vezes classificado como "preguiça" e "privilégios" dados pelo babalorixá. Alguns entrevistados chegam a corroborar esta ideia, como Ana:

Ai tem que lavar o prato, tratar a galinha, nunca tinha pego uma galinha antes de entrar no candomblé. Até hoje, se eu puder, eu fujo. Tanto que eu sou conhecida, eu, Silvia e Rita. Iá briga com a gente, dizendo que nós somos as preguiçosas de lá. Realmente, varrer chão, pra lavar, até minha mãe olhava pra mim e ficava me criticando, 'ah, em Paripe, por que em Paripe você faz? E em sua casa não?’

No entanto, tais posturas não podem ser pensadas como fechadas, inalteráveis e com significado estável (tampouco pode-se pensar que a avaliação por parte dos outros filhos de santo é homogênea, sempre de crítica). Ana prossegue um pouco mais à frente, depois de relatar o choque inicial com a vida no terreiro:

As pessoas criticam, 'ah, filhinha branquinha, filhinha preguiçosa, filhinha isso, a filhinha aquilo', já falaram sim. Mas tinha as irmãs que eram boazinhas, me ajudaram até um pouquinho. [...] Como Regina, ela via o meu desespero porque eu tratava galinha nas pontas dos dedos pra não sujar a mão. Quer dizer, eu acho que foi coisa de chatice mesmo, educação mal dada.

A última parte da fala de Ana aponta para algo de extrema importância aqui. Não apenas como argumentou McNay (1999), que a inadequação do habitus às exigências do campo é a condição de emergência da reflexividade, mas esta pode se voltar para uma valoração negativa da conduta própria e não da alheia, mas este ponto será retomado mais adiante. Por ora quero me ater a um dos elementos de sua formulação: o vocabulário em que as pessoas expressam a inadequação entre disposições e situação concreta é o do desconhe- 
cimento e da limitação das possibilidades de agir. Na fala de Marta, isto é muito mais evidente:

Elas [as ebomis] reclamam que a gente é lerda, mas nunca na vida me ensinaram a tratar galinha.

Foi o que ela comentou comigo ao sermos repreendidas por ainda não termos terminado a finalização da limpeza das aves que seriam cozidas para a festa naquela noite. O problema com as galinhas é interessante porque aponta para muito mais do que um desconhecimento cognitivo, sugerindo que aprender é uma reivindicação de certos gestos e certas sensibilidades. De fato não é qualquer pessoa dos círculos de classe média que pode pegar uma ave recém-sacrificada, ainda quente, "despir" sua pele coberta de penas com as mãos e depois mergulhá-las em suas entranhas para retirar seu interior. É preciso ter um certo jeito de segurar, aplicar uma certa força e em certas direções. Além de tudo, não é qualquer pessoa que pode manipular as vísceras dos animais oferecidos, pois certas partes (coração e "miúdos") contém axé. É preciso saber também quando parar de realizar a tarefa. Talvez o interesse despertado por esta atividade em especial resida em seus aspectos sensoriais. Entrar em contato com sangue, com corpos de animais abatidos é uma das maneiras como o candomblé requer o engajamento de seus membros e que tem grandes probabilidades de entrar em choque com a experiência cotidiana de muitos habitantes das grandes cidades, sejam eles de classe média ou não. No entanto, para estes especialmente, no terreiro, havia um despreparo para tais afazeres, que são atividades manuais desvalorizadas em nossa sociedade. Mesmo uma pessoa que saiba executar todas as tarefas domésticas dificilmente apresentará as disposições necessárias para desempenhar com destreza o que é exigido, devido as suas dimensões: tudo no terreiro é excessivo, as panelas são enormes, os pratos são incontáveis, a comida é preparada em quantidades "industriais". No caso das pessoas de classe média, a socialização distante dos terreiros de candomblé não favorece a incorporação precoce de tais disposições. Entretanto, quanto a isto, é interessante 
ressaltar um contraste surgido nas entrevistas. Enquanto que a questão da "boa educação" apareceu como um forte demarcador de posição social, o aprendizado de tais tarefas não foi desvalorizado como "propriedade" de um grupo de status mais baixo. Isto sugere que tais gestos, quando apropriados pelos indivíduos pesquisados, são tidos como "propriedade" do grupo religioso, não diminuindo necessariamente o status daqueles que os desempenham.

Dessa forma, uma boa parte dos conflitos emergentes nas interações concretas entre membros do terreiro pode ser interpretada não nos termos da "preguiça" de que são acusados - muitas vezes observei iaôs que não eram de classe média "fugindo do pesado", escondidos pelos cantos da roça, fazendo um lanche ou fumando -, mas em termos da inadequação das disposições às exigências das tarefas. Mesmo aquelas mais simples, como varrer, requerem um certo uso do corpo que não estava disponível para pessoas como Ana, que sequer lavava pratos em casa. Evidentemente, por ser mulher tive acesso muito maior aos comentários das mulheres (além da experiência direta) e pude observar seus comportamentos muito mais de perto, pois ficava restrita a sua área de atividade. Tenho apenas os relatos dos homens quanto ao que passaram e algumas observações. De toda maneira, foi possível perceber que para eles as atividades envolvem muito mais diretamente a força física. São eles que auxiliam nas obras do terreiro, carregam sacos de cimento, quebram paredes, como disse Pedro e são encarregados de tratar os animais de maior porte, bodes e cabras, oferecidos aos orixás. Fábio mencionou explicitamente esta experiência ao relatar seus primeiros meses no terreiro. Como já foi dito, ele conheceu a roça em seus primórdios, quando ela tinha poucas construções e ele sequer havia completado 20 anos:

E uma coisa que eu gostei de lá também, foi que tinha muita gente da minha idade. Porque se eu chegasse num lugar que tivesse um bocado de velho, que ficasse sentado, que eu ia pra Paripe eu tava com 17, eu ia fazer o que lá? Então, lá a gente jogava dominó, a gente jogava buraco, a gente carregava pedra nas costas. Os filhinhos de papai da Barra, 
que era como a gente era chamado lá, carregando pedra nas costas. [risos]

As críticas dirigidas aos filhos de santo de classe média nos termos da preguiça e do privilégio têm um pressuposto voluntarista e reducionista ao mesmo tempo. Reducionista porque equaciona classe - no terreiro sentida como algo que se expressa no bairro de residência, no automóvel e no emprego formal - a um comportamento homogêneo: fazer apenas os trabalhos "leves" de decoração ou participar somente quando os rituais já estão preparados. Nesse sentido, ela pode ser considerada como uma categorização dessas pessoas, pelos demais membros com quem interagem (JENKINS, 2000), com a qual nem sempre concordam, tampouco correspondem. Voluntarista porque pressupõe que basta ao indivíduo desejar para que possa desempenhar uma tarefa.

É verdade que as pessoas aqui focalizadas permanecem menos tempo no terreiro, não comparecem às quartas-feiras ${ }^{102}$ - em geral, mas Marta passou seu último ano de abiã indo praticamente toda semana - para ajudar na execução dos ebós e muitas vezes permanecem alheias às atividades de limpeza e preparo da comida, o que dificulta seu aprendizado das tarefas. Contudo, isto não pode ser generalizado e, ao menos os dois primeiros pontos estão diretamente correlacionados ao seu estilo de vida regulado pelo compasso do emprego formal de 40 horas semanais, às vezes mais. Mesmo pai Dary não reside o tempo todo na roça, dividindo seu tempo entre ela e seu apartamento na Cidade Baixa, muito mais próximo aos seus dois locais de trabalho, uma clínica particular e um posto municipal de saúde. O ritmo de atividades do próprio terreiro se encontra marcado pelo ritmo do mercado de trabalho formal. Além disso, esses profissionais de classe média permanecem mais próximos das atividades do terreiro nos primeiros anos logo após a iniciação, o que pode ser generalizado para adeptos de qualquer classe social.

102 Devido à agenda profissional de pai Dary, as quartas-feiras são os dias preferenciais para a realização de consultas e ebós. 
Quando perguntados se havia conflitos de horários entre suas outras atividades - trabalho, lazer, família - e as religiosas, vários deles me contaram (inclusive os de outros terreiros) que já haviam participado mais ativamente, mas que naquele momento, não iam com tanta frequência. ${ }^{103}$

Assim, ao contrário da interpretação "nativa" que acentua a falta de "vontade", as dificuldades na execução do preparo das cerimônias apontam exatamente para o ponto central do processo de autoidentificação com a religião: trata-se de uma apropriação das disposições adequadas. Trata-se de "apanhar" um gesto, voltar-se para ele e realizá-lo sem que seja necessário refletir. Esta apropriação é possível porque a imagem corporal - a integração esquemática de suas possibilidades - não é estável, embora tampouco seja totalmente fluída. As novas possibilidades do corpo podem ser, aos poucos, incorporadas e executadas sem qualquer problematização, como no caso de Fábio, que prosseguiu após rir um pouco, quando eu perguntei se eles "batiam laje":

Batendo laje. Só que era prazeroso pra gente porque a gente saía daquele mundo que a gente vivia. Porque eu, você me perguntou 'qual a classe que você se enquadra?', 'Classe média baixa'. Mas só que essa classe média que eu vivo aqui, é um mundo totalmente diferente de você ir pro subúrbio, entendeu? A gente passa a ter um convívio com pessoas totalmente diferentes. Então a gente era os filhinhos de papai da Barra, carregando pedra nas costas.

É também a situação de Pedro que hoje se encontra à vontade com as atividades na roça:

Eu aprendi com o convívio, logo no começo do candomblé, quando eu realmente fiz o santo, eu aprendi o seguinte: ogã é pau pra toda obra. E isso eu aplico em mim, não em to-

${ }^{103}$ Outro ponto interessante é que o trabalho tem prioridade sobre a presença no terreiro, mas não as atividades familiares. Quando são obrigados a escolher entre essas duas últimas, a roça é preterida em casos considerados excepcionais, como o aniversário de 90 anos da tia-avó de Fábio. Evidentemente, isto gera mais conflitos familiares. 
dos os ogãs lá da roça, nem em outros ogãs de outra roça, mas eu aplico em mim, se precisar tocar eu toco, se precisar cantar eu canto, se precisar cortar eu corto, se precisar vestir o santo, eu 'visto'... Se precisar despachar o santo eu despacho, se precisar pintar eu pinto, se precisar quebrar uma parede eu quebro, se precisar carregar um saco de cimento eu carrego. (ênfase na entonação).

A fala de Pedro evidencia o que várias pessoas chamaram de "o grande aprendizado" que representou seu ingresso no candomblé. Aqui fica claro que esse aprendizado dizia respeito, basicamente, a duas questões: aprender a executar atividades desconhecidas e a conviver com pessoas muito distintas. Em ambos os casos trata-se de muito mais do que uma mudança de representações. É preciso aprender a interagir, a se situar bem diante do outro e dentro das regras do grupo. Isto significa executar e compreender gestos e tons, muito mais do que aprender conteúdos objetivos. Aprender a executar tarefas é aprender uma maneira de mover-se, de dirigir-se para certos objetos - por exemplo, a galinha a ser limpa - sem que os próprios gestos sejam objeto de reflexão, o que dificulta a realização das mesmas, ao mesmo tempo em que expressa a inadequação. Como escreveu Merleau-Ponty (1962, p. 142), “[...] é o corpo que 'apanha' e 'compreende' o movimento" e é a imagem corporal que se alarga, incorporando os "instrumentos" (ou apetrechos) com os quais o corpo aprende a se mover e é sempre como um corpo socialmente situado que este se lança a esse aprendizado. Isto quer dizer que as dificuldades, as recusas, os desgostos (e, sobretudo, o nojo que se sente em certas circunstâncias) dizem algo a respeito da posição de tais sujeitos num espaço constituído por valorações socialmente construídas. (BOURDIEU, 2001a, p. 164)

Pode-se objetar que todas as pessoas acima mencionadas que se saíram bem neste processo de aproximação ao terreiro eram bastante jovens (entre 17 e 20 anos), mas situações semelhantes foram narradas por pessoas que chegaram bem mais velhas ao candomblé, tal como Irene, que se iniciou aos 46 anos. 
Irene - É, na verdade foi, mas ele [seu companheiro] foi iniciado primeiro do que eu. Que ele... ele ficô lá e logo ele foi levantado ogã, foi confirmado e eu fiquei. Primeiro eu era, quando eu cheguei lá, eu fui... eu era 'mulher de ogã', as pessoas me serviam, tudo, né? E depois, nem entendo mesmo como é que foi que eu deixei de ser 'mulher de ogã ' e passei a ser abiã. Quer dizer a ...

Luciana - Aí mudou completamente a posição na hierarquia. Irene - Ai mudou completamente, ao invés de ficar sentada naquele lugar lá, que é destinado pras mulheres dos ogãs, ai eu ficava cá, ah! Junto com Antônia! [também entrevistada] Que Antônia na época também era abiã. Né? Então a gente ficava junto, lavava muito prato. Servia as pessoas na festa, né? Fazia os menores trabalhos que tinha pra fazer, a gente fazia. (ênfase na entonação).

Desse modo, o estilo próprio do candomblé de requisitar o engajamento de seus membros, mesmo fora dos momentos rituais propriamente ditos, possibilita a incorporação de novos gestos, novas posturas ao esquema corporal. A pessoa se torna capaz de fazer coisas que desconhecia, como tocar os atabaques nos variados ritmos das divindades. Esta apropriação - é disso que se trata, de tornar "apropriado" e também "meu próprio" - é sustentada pelo arco intencional. Ela é uma maneira de voltar-se para as tarefas, para os gestos, para os sons, para o mundo. Não se restringe a uma suposta "vida interior" do sujeito, mas dirige-se para "fora", para as ações e os outros. Ou melhor, ela estabelece, num mesmo movimento, os limites das capacidades e do contexto onde elas passam a existir. Elas delimitam a experiência que é simultaneamente de si e do mundo. Assim, passar a ser de candomblé é uma maneira de se situar frente ao mundo e de dirigir-se a ele. Como foi argumentado no capítulo anterior, o modo de se relacionar e interagir no universo social é fundamental para a identidade pessoal. A autoidentificação com o candomblé é um mesmo processo em duas direções simultaneamente (JENKINS, 2002, p. 275): em direção ao sujeito e ao seu mundo. 
Sugeri acima que o candomblé tem um estilo próprio de solicitar o engajamento de seus participantes. Embora as atividades e tarefas mencionadas sejam importantes para a compreensão de como se desenrola o processo de autoidentificação de profissionais de classe média com o terreiro, é preciso considerar, agora, um aspecto de fundamental importância. Trata-se de uma religião e, portanto, é essencial atentar para suas proposições acerca do plano espiritual também do ponto de vista do engajamento corporal dos sujeitos.

\section{INCORPORANDO HABITUS E DIVINDADES}

De acordo com a perspectiva analítica desenvolvida aqui, o candomblé pode ser pensado como construção de possibilidades de exploração do mundo pelo sujeito. Considerar os aspectos pré-reflexivos da ação e o engajamento corporal em atividades com outros, é o mesmo que apresentá-la como uma forma de se dirigir ao mundo, de lançarse em atividades e interações. Alguns pontos específicos ao grupo religioso já foram mencionados com relação à hierarquia, ao vestuário e aos trabalhos de preparação dos rituais. A seguir serão considerados momentos mais "próximos" à incorporação das divindades, isto é, situações que ocorrem em rituais propriamente ditos.

Em geral, as festas do candomblé se iniciam com o xirê, uma espécie de abertura na qual os ogãs tocam os ritmos dos vários orixás e os filhos da casa dançam numa roda. É o momento inicial de saudação às divindades. Mesmo antes que estas desçam nos corpos de seus filhos, esta fase do ritual já apresenta um elemento interessante para consideração: a maneira de dançar que esta religião solicita não é a mais usual em nossa sociedade, ao menos para pessoas de classe média. Os vários ritmos tocados são relacionados a certos passos e estilos de movimento diferenciados, correspondentes a cada orixá. Por exemplo, as danças das iabás das águas, Oxum e Iemanjá, envolvem gestos suaves, um uso dos braços que ocupa mais o espaço ao redor dos quadris, enquanto que a dança de orixás como Ogum e Iansã são pródigas em movimentos mais rápidos e retilíneos, que ocupam mais 
a frente e o alto. (BÁRBARA, 2000, p. 57-58) Começar a aprender tais movimentos é uma tarefa árdua para aqueles que não cresceram no ambiente de um terreiro, sejam eles de classe média ou não. Os que são familiarizados na roça desde a infância apresentam menos dificuldades. É comum ver crianças pequenas imitando a dança na roda, fazendo sua própria dança em locais menos visíveis ou imitando os orixás. Para elas, essa é uma forma de exploração do espaço ao seu redor com a qual contam desde sempre. Para quem vem de outros contextos, no entanto, é necessário aprender a desempenhar os gestos.

Os movimentos de dança no candomblé exigem uma postura dos pés, envolvendo o apoio sobre toda a sola, e não somente sobre as pontas dos mesmos, tal como é indicativo de elegância feminina em nossa sociedade, vide a popularidade dos saltos altos. ${ }^{104} \mathrm{Pude}$ observar que algumas das melhores dançarinas costumam inclusive levantar os dedos enquanto dançam, mantendo-se totalmente sobre as plantas dos pés. Muitas vezes os orixás incorporados também fazem isto. Além disso, há uma variedade de passos calcados em contratempos que seguem os difíceis ritmos dos atabaques e um amplo uso do espaço lateral do corpo. Tal estilo pode não ser problemático para quem cresce sabendo sambar à moda baiana, que consiste numa alternação rápida dos pés à frente e atrás, enquanto que os quadris se movem para os lados, para cima e para baixo, num ritmo contínuo. Para quem cresce num mundo onde os gestos podem ser coordenados de tal maneira, em várias direções ao mesmo tempo, captar os movimentos de dança do candomblé pode ser muito simples. Entretanto, para quem vem de um universo onde o corpo é educado nos ritmos da Educação Física dos colégios, ou das academias de ginástica, dança e esportes é bem mais problemático. Uma boa parte dos movimentos exigidos nestes ambientes mantém o equilíbrio através de uma divi-

${ }^{104}$ É interessante notar a diferença marcante entre as danças das mulheres iaôs e das ebomis no xirê, especialmente quando estas têm mais idade. Enquanto as primeiras parecem esmerar-se em executar os passos de cada ritmo de modo que sejam claramente diferentes entre si, as ebomis parecem exibir um "domínio contido" dos passos que parece tornar todos eles um pouco uniformes e ainda assim preservar alguma diferenciação. 
são do corpo em duas metades laterais, enquanto uma se projeta, a outra sustenta o peso. É usual, por exemplo, que ao projetar o braço direito à frente, a perna esquerda vá para trás. Nas danças do xirê o equilíbrio é mantido de maneira muito mais próxima à da Capoeira ou de artes marciais orientais: jogando-se o peso sobre as plantas dos pés e os joelhos. A ideia parece ser que o equilíbrio é alcançado por uma forma "equânime" de assentar o corpo sobre o chão, isto é, do modo mais bem distribuído possível, sem se basear numa oposição coordenada do lado esquerdo e do direito para que um contrabalance o movimento do outro. Muitos movimentos das danças no candomblé exigem que perna e braço esquerdo, por exemplo, movam-se na mesma direção ao mesmo tempo.

Assim, os primeiros passos de dança no candomblé vêm como um esforço consciente para executar os movimentos adequados. Mesmo para aqueles que já trazem algumas disposições incorporadas que tornam o aprendizado menos problemático, o início do processo ainda pode exigir uma objetificação dos gestos: procura-se atentar para as sequências de movimentos, para uma certa flexão dos joelhos ou braços, para toda a postura e para o ritmo. Algumas pessoas nunca aprenderão a dançar bem, outras, mesmo de classe média e chegando tarde da vida aos terreiros, podem aprender. De toda a forma, o que o processo envolve é a transformação dos gestos de esforço reflexivo em movimento espontâneo, ou seja, trata-se verdadeiramente de uma incorporação dos gestos adequados.

Um movimento é aprendido quando o corpo o compreendeu, isto é, quando o incorporou em seu "mundo", e mover seu próprio corpo é mirar as coisas através dele, é permitir-se responder ao seu chamado, que é dirigido ao corpo independente de qualquer representação. (MERLEAU-PONTY, 1962, p. 139)

Desta maneira, a incorporação de novos gestos é a incorporação de uma nova maneira de voltar-se para o mundo e interagir com os objetos que lá estão. Aprender a dançar é ter incorporado as roupas 
diferentes que se usa e o entorno onde se dá o movimento de tal forma que nenhum de seus elementos precise assomar à consciência. É não sentir mais o equilíbrio do próprio corpo, pois ele já retornou ao horizonte dos gestos possíveis, não precisando mais ser tematizado. Quando consideramos que "se mover" é um modo de estar no mundo, imerso em suas distâncias e lugares, vemos que é uma forma de perceber, de explorar e interagir com o entorno. Este, porém, nunca é um espaço abstrato, mensurável, objetivo - aquele compreendido em metros e coordenadas -, mas sempre um espaço situado em relação ao ponto de vista do sujeito encarnado (MERLEAU-PONTY, 1962, p. 107-108), é um espaço que sustenta suas possibilidades e incapacidades. Além disso, é um espaço compartilhado que carrega valores e afetos intersubjetivamente investidos numa espécie de topografia sociocultural. (BOURDIEU, 2001a) A reiteração da importância de movimentos e gestos se deve à sua adequação para enfatizar que entrar no mundo do candomblé não se limita ao compartilhar de certas ideias e representações, mas também de uma série de disposições incorporadas.

O candomblé coloca ainda uma solicitação mais radical aos corpos de muitos de seus iniciados: eles devem receber seus orixás, erês e caboclos. No capítulo anterior foram destacadas as relações dos filhos com suas entidades pessoais. Dentre estas destaquei a ação dos deuses na vida dos seres humanos como um elemento fundamental à compreensão do mundo religioso e, portanto, no qual têm lugar os processos de autoidentificação. Agora, focalizando especificamente os movimentos pelos quais o candomblé dirige a exploração do entorno por seus participantes, é preciso retomar esta questão. Boa parte dos esforços rituais tem por objetivo regular a incorporação das entidades, que muitas vezes se dá de forma "desordenada", como nos casos em que as pessoas começam a "dar passagem" a caboclos e exus, principalmente, fora do ambiente de um terreiro. Também é comum que frequentadores não iniciados e abiãs "passem mal” durante certas cerimônias, isto é, que sintam a presença do orixá, mas não os 
incorporem completamente. Nestes casos, pode-se sentir taquicardia, tonturas, frio ou calor, ter suores, a visão turva, ou muitas outras sensações de mal-estar. Os entrevistados que admitiram ter passado por um período de manifestação “incompleta”, afirmaram ser muito desagradável permanecer neste estado:

Porque tu sente, tanto assim que, a minha experiência ainda é recente nessa coisa, né? Uma sensação, assim, depois que passa aquele minuto, aquele, não sei quanto tempo, pouco tempo, tu tá transpirando, tu tá... é uma descarga de energia muito grande. (Marta).

Nos terreiros também é possível observar com frequência pessoas passando por tal situação, precisando ser amparadas por alguém ao lado, girando sobre si mesmas ou tentando fugir do barracão. No período em que frequentou o terreiro, Rosana passava com frequência por esta situação, ameaçando perder o equilíbrio e apoiando-se em quem estivesse ao lado, com olhar esgazeado. Segundo ela, a ideia de "sair do ar" era assustadora e, justamente, esse elemento era utilizado por uma das filhas de santo da vizinhança para atormentar Rosana em momentos de descontração, afirmando que ela iria "rodar”, que o santo iria "lhe pegar".

A iniciação "normaliza" a passagem do orixá e um iaô novo tende a receber o dono de sua cabeça em praticamente todos os momentos rituais que favoreçam a decida da divindade, como boris e oferendas feitas no terreiro. Nesta "preparação" uma grande atenção é dirigida ao corpo que é manipulado de diversas formas, numa longa série de rituais que visam estabelecer, ou “equilibrar”, como dizem os membros do Torrundê, a relação com as divindades. (BASTIDE, 1983; RABELO; MOTA; NUNES, 2002; RABELO, 2005) Os cabelos são completamente raspados e pequenas incisões, chamadas curas, são feitas nos braços, nas omoplatas e no alto da cabeça. Substâncias sagradas são preparadas e colocadas sobre estes cortes. As curas devem permitir a comunicação do axé e o contato com os orixás. Ao mesmo tempo são inscrições, no sentido que demarcam o pertencimento da 
pessoa a um grupo. Elas são de fato "sinais”, mas que “abrem” o corpo e não apenas apontam para algo além dele, ou melhor, se as curas "significam" algo é exatamente as possibilidades construídas pela iniciação, pois não se trata apenas de uma inscrição, mas também de abertura e fechamento. Seguindo a proposta de Budegeon (2003), no esforço de ultrapassar a dicotomia entre representação e materialidade, é preciso perguntar-se não somente como a cultura inscreve seus significados nos corpos, mas também o que estes "podem fazer".

Como vimos ao considerar a identidade espiritual, as possibilidades de incorporação das divindades são diferentemente articuladas no interior da tradição de cada terreiro, ou de famílias destes. (NICOLAU-PARÉS, 1997, p. 149-172) Assim, se trata de uma verdadeira construção de possibilidades e de eliminação de outras. Por exemplo, em muitos terreiros, como no Torrundê, há culto aos caboclos, portanto, a incorporação por estes é uma possibilidade encorajada a todos os filhos de santo. Alguns chegam ao terreiro já recebendo seus caboclos em casa ou em outras circunstâncias. Outros são iniciados, seu orixá de cabeça se manifesta, bem como seu erê, mas não seu caboclo. De qualquer forma, o caboclo está sempre presente no horizonte de possibilidades destas pessoas. Ao contrário, a incorporação por Exu não. Em muitas casas o culto a este orixá é feito sem sua presença nos corpos dos filhos. Os membros da roça não devem receber Exu. No entanto, várias pessoas chegam ao Torrundê apresentando esta manifestação. Uma das primeiras providências, nestes casos, é fazer uma limpeza e procurar agradar ao orixá para que pare de tomar o corpo da pessoa. Na verdade, a teoria local afirma que não se trata do orixá Exu propriamente dito, mas que ele pode usar a energia de alguns eguns e misturar-se a ela para poder incorporar. ${ }^{105}$ Embora muitas pessoas tenham boas relações com seus Exus e Pombagiras - que dão conselhos e ajuda -, no terreiro isto não é visto com tranquilidade. Assim, ao lado da proposição de abertura do corpo, o candomblé também opera uma restrição referente à tradição

1050 mesmo tipo de explicação é encontrado no já referido terreiro da irmã de santo de pai Dary. 
religiosa da casa, sem contar os ogãs e equedes a quem, uma vez feita a confirmação, é vedada qualquer possibilidade de incorporação.

O corpo no candomblé é a morada da vida individual e das forças sagradas, mesmo que estas se manifestem visivelmente apenas em alguns momentos apropriados. Pessoas recém-saídas da reclusão, tanto equedes e ogãs como iaôs, têm que manter uma série de cuidados especiais durante longos períodos que variam de 21 dias a três meses - podendo durar até um pouco mais, caso o orixá expresse esta necessidade no jogo de búzios. Durante esse período o novo membro da casa deverá vestir-se exclusivamente de branco, cobrir a cabeça com algum chapéu, boné, lenço ou assemelhado, usar quelê e contra-egun, não poderá manter relações sexuais, nem fumar, beber ou tomar banho de mar. São os resguardos, que devem ser cumpridos à risca para não pôr em risco a saúde física e emocional do iniciado recente. Algumas destas proibições podem se estender por períodos mais longos, como a abstinência de bebidas alcoólicas e dos banhos de mar que, em certos terreiros, dura até um ano. Algumas sofrem variações de acordo com o orixá do iniciado, como Oxalá, por exemplo, que pode exigir que seu filho use branco por muito mais tempo, ou mesmo pelo resto da vida. Além disso, há as quizilas, proibições alimentares correspondentes aos orixás. Cada pessoa deverá evitar tanto as quizilas do seu santo, quantas as de sua ialorixá ou babalorixá. Estas proibições alimentares constituem um ponto interessante, pois sua quebra causa reações imediatas que, muitas vezes se parecem com uma intoxicação alimentar, podendo causar vômitos e erupções cutâneas. Assim, trata-se de um amplo conjunto de ações cujo foco central se encontra na corporalidade dos adeptos religiosos que estabelecem tanto o que os corpos podem fazer como o que não podem mais.

No entanto, é preciso ressaltar que toda esta atenção dirigida ao corpo não tem por objetivo, nem por resultado, estabelecer uma oposição entre "corpo" e "consciência”. Mesmo que a materialidade física seja tomada como "objeto" das manipulações rituais, o sen- 
tido dessas ações não se estabelece na rejeição das potencialidades corporais - embora consista numa elaborada regulação destas como algo oposto à mente ou ao espírito. Como argumentou Weiss (1999), não há razão para supor que toda atenção dirigida ao corpo seja necessariamente restritiva às potencialidades do sujeito. Não se trata, exatamente da retomada reflexiva do próprio corpo enquanto um objeto da vontade, como na análise de Giddens (1991), ao menos, não da vontade individual. Se esta atenção toma o corpo como objeto é no sentido de reconfigurá-lo para voltar-se de novas maneiras para o mundo. Mais ainda, para um mundo religiosamente constituído, no qual o sagrado tem seu lugar junto aos seres humanos, perpassando seus corpos, quer se torne visível na incorporação das divindades ou não. Este é um ponto fundamental para compreendermos a especificidade radical do candomblé. Como foi indicado de várias maneiras diferentes durante todo este trabalho, a religião aqui tratada não se assenta primordialmente sobre uma dicotomização, mas sim sobre dualidades que se completam e imiscuem umas nas outras. É preciso, no entanto, considerar mais atentamente a relação dessa particularidade com a do mundo das pessoas aqui tratadas.

Ao solicitar o engajamento corporal de seus adeptos das maneiras citadas, o terreiro de candomblé desafia muitas das fronteiras corporais presumidamente naturais para pessoas de classe média. Mobilizando todos os órgãos sensoriais e ainda avaliações muito próximas ao corpo, como a vergonha, os limites da exposição, do conforto e da destreza, além da radicalidade da incorporação do outro sagrado, esta religião desafia os limites do indivíduo social, psicológica e religiosamente. Ao fazê-lo, o candomblé estabelece simultaneamente o mundo em que tais fronteiras são reconfiguradas, uma vez que definições de interior, exterior e do que pode trespassar seus limites, do que é visível e do que deve permanecer invisível sustentam a coerência tanto da existência encarnada quanto da própria cultura. (WEISS, 1999, p. 89) O mundo - enquanto for mundo humano tal como o conhecemos - nos é dado através da sua exploração pelo corpo e, 
confrontando suas possibilidades, nos dá a conhecer ao mesmo tempo o próprio corpo.

Colocar o corpo como objeto de grande atenção é uma forma de conhecê-lo, mas isto não significa somente ter dele uma representação objetiva bem elaborada, e não é isto o que esta religião propõe. Mais ainda, conhecer meu corpo é fazer uso de suas possibilidades como minhas - pois é isto que elas são - , ter um senso do que me pertence neste mundo. As posições, reações, gostos, gestos me pertencem e têm sua unidade sustentada pelo arco intencional através do qual mantenho-me ligada a elas. Este arco que sustenta as formas de voltar-se para objetos, sendo constituído por este mesmo movimento de "atenção", refere-se à sedimentação de certas maneiras de lançar-se em ações mantidas no horizonte do sujeito. Embora, as formas de se dirigir ao entorno sejam sempre atuais, isto é, existindo no presente de sua ação, correlacionam-se intimamente com o passado e o futuro:

$[\ldots]$ a consciência se projeta no mundo físico e tem um corpo da mesma forma em que se projeta num mundo cultural e tem seus hábitos: porque ela não pode ser consciência sem contar com significações dadas tanto no passado absoluto da natureza quanto em seu passado pessoal e porque qualquer forma de experiência vivida tende para uma certa generalidade, seja aquela de nossos hábitos, seja aquela de nossas 'funções corporais'. (MERLEAU-PONTY, 1962, p. 137) ${ }^{106}$

\footnotetext{
106 É importante ressaltar que, para Merleau-Ponty, assim como para Bourdieu, a natureza não é o que jaz para além do "trabalho" da cultura, não é um mundo físico puramente objetivo independente da ação humana. A natureza é, antes de tudo, um resultado de uma sedimentação tão bem-acabada das significações que pode inclusive cumprir o papel de já dado na experiência, tal como as funções do "organismo" que, embora não existam independentes de sujeitos encarnados (concretos, culturais), permitem a coexistência de um certo nível de "processos em terceira pessoa" com a experiência pessoal. Este nível de "despersonalização" existente na vida da consciência é de extrema importância para evitar o idealismo, pois ele opera como limite concreto às explorações desta. Mais uma vez, porém, ele é dado no âmbito sociocultural, nas matrizes do habitus de Bourdieu e não numa "natureza objetiva".
} 
É preciso reiterar que essa operação sempre renovada no presente da ação não é desprovida de sentido nem mesmo nos menores gestos, uma vez que conta com o constante pano de fundo do mundo e do corpo próprio. Ao iniciar um movimento dos mais simples, como coçar a orelha, o sujeito lança-se a uma ação que tem sentido e direção: ela volta-se para um fim. Entretanto, a questão de como pode haver sentido no que é eterno fluxo e renovação pode sempre ser contraposta a esta formulação. Como argumentou Jenkins (2002) é a própria materialidade corporal e do entorno o que sustenta a permanência em meio ao movimento constante. A solidez física dos corpos e ambiente permite a sustentação dos liames intencionais que o mundo solicita em sua forma especificamente cultural de existência. Assim, as formas de voltar-se para o mundo participam da autoidentidade, pois se imiscuem na própria base das relações nas quais o "eu" se situa com relação a ele. Os modos específicos de engajamento nas ações são apropriados na identidade pessoal, de maneira semelhante à qual o habitus, por sua força integradora, constitui um estilo de vida.

No caso dos terreiros, a apreensão de gestos adequados que passam a ser executados sem reflexão tem duas consequências importantes para este argumento. A primeira é que, considerado como um espaço entre outros, a roça se torna um lugar onde se pode - e deve ir - ao invés de um lugar distante e inadequado. Neste sentido, podemos dizer que os indivíduos de classe média realizam uma verdadeira ultrapassagem de fronteiras sociais ao vincularem-se a um terreiro, especialmente àqueles que se situam em bairros mais distantes da periferia. Dessa forma, já podemos dizer que o vínculo com o candomblé "muda como a gente vê as coisas". A periferia (uma minúscula parte dela, é verdade) é apropriada pelo trânsito dessas pessoas em seu mundo mais próximo. A outra consequência é que novas formas de exploração do entorno significam novas formas de apreensão do mesmo. Como vimos acima, as possibilidades exploratórias do corpo participam do senso de unidade que possibilita a mais 
básica autoidentificação: saber que meus gestos são de fato meus. Como sustentou Jenkins (2002) é a própria solidez da corporalidade individual que oferece alguma estabilidade aos processos contínuos e sempre abertos de autoidentificação.

Assim, é possível que surjam novas avaliações e percepções no processo de autoidentificação com um terreiro, uma vez que estas emergem da prática. Ao serem apropriados pelos sujeitos, estes modos de exploração e interação passam a fazer parte de seu horizonte de possibilidades e, assim, contam como pano de fundo sobre o qual são recortados os objetos tematizados. É o horizonte que dá os contornos da figura: somente contra seu pano de fundo ela pode tornarse perceptível. Até mesmo o corpo próprio quando retomado como objeto de reflexão, passa a ter o candomblé como um de seus horizontes de sentido. Ou melhor, ele mais facilmente do que outros aspectos da vida pessoal, uma vez que muito das manipulações rituais o solicitaram e podem ser evocadas em diversas sensações, como quando da desobediência a uma quizila que provoca uma reação corporal violenta e desagradável. É dessa maneira, incorporando-se aos horizontes dos sujeitos que elementos oferecidos pelo candomblé podem passar a fazer parte de seus habitus e estilos de vida.

No entanto, não há uma "transformação total”, podemos apenas falar de uma ampliação de horizontes. Assim, as pessoas investigadas podem continuar mencionando a falta de educação, a ignorância daqueles com quem passaram a conviver, sua falta de "seriedade" ou de "sinceridade" nas relações com o sagrado e com os demais membros e, ao mesmo tempo, avaliar positivamente sua convivência no terreiro:

A questão, financeira, social, é uma outra história, mas a principal mudança, ela é interior. A forma como você vê a vida, a forma como você 'busca' orientar e conduzir a tua vida e as pessoas que te buscam. Que tipo de orientação você pode dar, né? Então, a mudança maior é essa, é interior. E essa mudança eu só vim passar, tipo um ano e meio depois da iniciação. A partir dai ela veio se aprimorando, lógico, você começa a ter contato com 'mil' pessoas dife- 
rentes, com, classes sociais diferentes, né? Enfim, culturas diferentes, hum... a espiritualidade me deu... é, um, um, vamos dizer assim, uma dádiva muito grande que foi poder ter contatos com muitas pessoas. Em outros Estados, em outros países, né? Enfim, isso abriu muito o meu horizonte, muito. A nivel de amizades fora da Bahia e, sabe? Facilitou muito o meu entendimento de universo. Que era um universo muito limitado. Hoje, eu ter uma vida que eu veja das mais diversas formas, onde você pode ir do, da alta esfera, ao, ao povo simples, que passa fome, que tem necessidades e você consegue ajudar a esse que tá cá embaixo, orientando, dando uma palavra, enfim, dando direcionamento, como você pode ajudar a esse que tá lá cima no pedestal. Então, essa coisa do convívio com pessoas das mais diversas formas, talvez tenha sido a grande mudança da minha vida. (Pai Robson, ênfases na entonação)

Irene também explicitou uma posição próxima à de pai Robson:

Então, é, eu gosto quando eu sei que eu posso chegar na academia e fazer uma fala legal sobre o meu trabalho, né? Sobre o que eu faço hoje. Mas eu sei sentar com as velhas do [terreiro], lá na beira do meio fio da porta, e sei conversar com elas de um jeito que elas me entendem e eu entendo elas, mesmo porque elas são muito mais sábias do que eu. Muito mais. Muito mais. E, por exemplo, uma, as minhas melhores amigas, eu tenho uma amiga lá no terreiro, é uma pessoa, inclusive ela é mais nova do que eu, que eu chamo ela de mãe. Porque ela ajudou muito quando eu, quando eu estava recolhida, né? O nome dela é Maria. Maria de Iansã. Maria é de muito pouco estudo, ela deve ter talvez, uma quinta série... Mas ela tem coisas tão seguras pra dizer à gente quando a gente precisa.

De maneira semelhante, vimos na fala de Ana como sua inépcia e seu desgosto puderam ser retrospectivamente avaliados como "má educação". O que não a impede de continuar "fugindo" das tarefas que a desagradam. Podemos dizer que há uma incorporação de possibilidades de apreensão, avaliação e julgamento, mas que estas não 
se sobrepõem totalmente ao habitus já incorporado anteriormente. Alguns até mesmo expressaram que sentem uma diferença na sua forma de vivenciar a religião:

Eu resolvi adotar o candomblé como uma religião. Mas eu não me vejo como um adepto, crente, é... convencional. Eu tenho uma perspectiva pessoal da religião que a própria compreensão do fenômeno religioso me posiciona de uma forma que eu acho que é original dentro dos ritos, do processo de culto e que não é de se estranhar porque um sujeito que veio chegar no candomblé depois dos 40 anos de idade, não há de ser um, um fiel por educação fundamental, né? [...] O rito é alguma coisa que precisa ser reproduzida para assegurar que a religião persista como fenômeno social, né? Então eu não posso me distanciar disso se eu tô naquele ambiente que professa essa religião. Mas eu tô numa posição que me confere uma perspectiva que eu acho que é diferente do geral dos religiosos que cresceram no ambiente do candomblé. (Ernesto)

É impossível discernir nas interações concretas aquilo já está totalmente assimilado como uma disposição incorporada e aquilo que é fruto de um esforço reflexivo no que diz respeito às avaliações e percepções. Não seria possível, por exemplo, dizer se pai Robson recebe e orienta as pessoas do "povo simples" com uma abertura que já não tematiza sua condição de classe, ou se os recebe a partir das reflexões possibilitadas pela incorporação da convivência que mencionou. De toda forma, sua prática hoje envolve a interação com um grupo muito mais amplo de pessoas, o que ele considera uma ampliação de seus "horizontes".

Outro exemplo de persistência do habitus escolar pode ser encontrado na fala de Antônia a respeito das amizades que fez no terreiro:

E ai, quando eu vi, eu tava fazendo trabalho e fui fazendo amigos. Ai outros amigos foram chegando, ai foi se formando um grupo. Quando eu vi, eu tinha um grupo de pessoas lá dentro que eram minhas amigas fora do [terreiro] também. 
E que era na maior parte, 'era' na maior parte, não. Era essencialmente pessoas de nivel universitário, intelectuais que estavam na roça. Pronto, eu fui ficando, nesse ficar eu fui suspensa. Eu fui suspensa equede de Iansã. Mas quando eu fui suspensa eu já tava 'toda', já tava toda. (ênfase na entonação)

Evidentemente, Antônia deve ter admitido a particularidade "universitária" de seu grupo de amigos por saber que minha pesquisa era sobre profissionais de classe média. Isto não significa que ela tenha inventado tal fato, mas apenas que nossa situação de entrevista pode tê-la feito refletir sobre este ponto, atribuindo-lhe uma importância que poderia não existir anteriormente. De toda forma, sua relação mais próxima com os outros membros de classe média não é excepcional para que duvidemos dela. Também no Torrundê houve uma sobreposição entre o grupo de pessoas que me eram indicadas para entrevistas por serem consideradas de classe média e um dos subgrupos internos do terreiro que é constituído por pessoas amigas entre si, algumas antes do ingresso na religião, outras que se conheceram lá. Marta e equede Hortência não fazem parte desse subgrupo, mas são mais velhas do que seus integrantes cujas idades variam entre 25 e 30 anos.

Assim, podemos concluir que através da abertura do horizonte de possibilidades - de gestos, apreciações e relações - o terreiro pode fornecer novos elementos ao habitus e aos estilos de vida de tais pessoas. Não podemos, porém, concluir que o candomblé domina completamente o estilo de vida de seus participantes. O horizonte de suas experiências de classe ainda marca muito seus esquemas de avaliação e percepção. A questão é que um estilo de vida é justamente a expressão da força integradora do habitus através da aplicação de uma mesma matriz geradora de práticas e valorações aos mais diversos campos. Desta maneira a autoidentificação com o candomblé pode trazer novos elementos a essa matriz, por exemplo, como vimos no capítulo anterior, possibilitar a categorização de outros em 
termos dos orixás de cabeça, ou manter certos cuidados com relação ao corpo e ao vestuário. ${ }^{107}$ Entretanto este processo identitário não invalida a matriz anterior.

Podemos dizer, seguindo a análise de McNay (1999), que é justamente a inadequação das disposições de uma classe média escolar à convivência no terreiro que permite a emergência da reflexividade acerca das mesmas e, ao mesmo tempo, possibilita a inovação através da incorporação de novas disposições. Assim, passar a ser de candomblé permitiria uma certa ultrapassagem das posições de classe, mas não total, como vimos nas expressões de como esta posição é sentida nas interações. Mais uma vez, trata-se de um jogo entre determinação e indeterminação, uma apoiando-se sobre a outra, sem eliminação de qualquer um dos polos. Ao mesmo tempo, é também um jogo entre reflexividade e pré-reflexividade que opera na estrutura figura-horizonte de toda percepção: é sobre um certo horizonte que podem ser tematizados os objetos. Estes, porém, quando não tematizados se "retraem", mas permanecem disponíveis como horizonte para novas objetivações.

\section{PARTICULARIDADES INCORPORADAS}

Há ainda um ponto que merece receber alguma atenção. Se os orixás contam como agentes, podem compartilhar certas características com os outros (os seres humanos) com os quais coexistem neste universo cultural. Estas residem tanto em "traços de personalidades" quanto - ou ainda mais - em seus modos de agir. Sob este aspecto, as divindades são altamente pessoais, particularizadas. Por outro lado, como vimos anteriormente, uma concepção bastante difundida afirma que os orixás são energias da natureza. Nunca foram seres vivos nesta terra, portanto não são mortais. São entidades cósmicas - cada uma corresponde à energia de um elemento natural - que

107 No candomblé a cor negra para roupas é considerada como inadequada e a branca a mais correta. Por isso é muito comum que adeptos desta religião evitem indumentárias de cores escuras e mantenham um guarda roupas em tons claros. 
são individualizadas na iniciação, recebendo um nome próprio e uma morada no assentamento pessoal do iniciado, o ibá.

Por este ângulo, as divindades apresentam um caráter universal e não de referência a um passado pessoal ou coletivo, etnicamente ou localmente definido (PRANDI, 1999), exceto por aquele que se encontra estabelecido na tradição ritual de cada família de terreiros e que, por sua vez delimita as experiências com as divindades. Hervieu -Léger (1998, p. 216) propôs que nas sociedades "complexas” as comunidades de fé têm a base de sua memória coletiva assentada sobre um ato fundacional - uma nova revelação - , uma vez que se rompeu o vínculo entre o passado da coletividade religiosa e a própria criação do mundo tal como conhecemos. Isto pode ser aplicável aos grupos protestantes, bem como a todos aqueles que se assentam sobre uma "verdade revelada", o que dá amplo espaço para a figura de um profeta fundador, mas não é o caso do candomblé, cuja reivindicação de verdade se assenta a própria criação do universo que coincide com a criação dos orixás. O candomblé é a religião de culto a forças da natureza e, portanto universais. Entretanto, os modos “corretos" de culto (e até mesmo quais entidades devem ser cultuadas) são objeto de disputa entre diferentes linhagens de terreiros, o que os aproxima um pouco da proposição de Hervieu-Léger (1998). Desse modo, mais uma vez o candomblé parece apresentar os dois polos de uma dualidade: uma ontologia universalista e uma prática particularista. Mais uma vez é preciso retornar aos orixás para compreender a direção do processo.

Como vimos, os orixás são considerados como energias da natureza que dominam a vida de cada ser humano independente do conhecimento deste, e ao mesmo tempo, como a relação mais individualizada que mantêm com cada membro iniciado. Assim, os deuses expressam ao mesmo tempo a mais ampla generalidade, que diz respeito ao cosmos e a toda a humanidade, e a maior particularidade, tornando-se individuais na iniciação de seus filhos. O que os orixás mani- 
festam quando incorporados não é o poder de um passado específico de um grupo, mas forças cósmicas. ${ }^{108}$

No contexto de Salvador, as divindades não apresentam o caráter de ancestrais bem definidos, de familiares ou chefes políticos divinizados. Aqui, existe a ideia de que certos indivíduos podem ter orixás herdados de seus ascendentes, mas esta concepção não é bem sistematizada entre os entrevistados, como já foi mencionado:

Marta - Mas meu pai Dary fala de um orixá de ancestralidade, e ai ele fala, assim, nessa coisa de que a minha Oxum é de uma, hierarquia muito velha, muito...

Luciana - Antiga?

Marta - Não que ela seja velha, mas é de uma...

L: A linhagem dela?

M: A linhagem dela é muito antiga, e não sei o que, pererê, não é assim tão fácil aqui. Mas eu não sei se... tanto que a minha irmã ficou de encontrar, tá procurando lá essa única foto que a gente tinha da minha avó no candomblé, pra gente poder ampliar e começar a identificar, pela roupa, pelas contas...

L: Ah! De que orixá ela era...

M: Pra ver se a gente consegue. É. Porque a gente não tem essa...

L: Nenhuma?

M: Não tem, não tem. Mas parece que essa minha Oxum é, eu não sei se... se ela não, pra mim ela vem da minha vó, vem da, vem desse lado de minha vó.

Através de reticências, retomadas, hesitações, Marta tentava me explicar como compreendia sua ancestralidade no candom-

108 Quanto a isto, é imprescindível ter em mente que a quase totalidade do trabalho de campo para esta pesquisa foi realizado num terreiro aberto pelo seu atual líder (isto é, que ainda não atravessou gerações de adeptos de modo a conformar uma memória coletiva de um passado altamente valorizado) que vem de uma família católica e espírita, sem "raízes" conhecidas no candomblé. Talvez seja possível encontrar concepções muito distintas em terreiros antigos. 
blé. Tentei trabalhar esta questão tanto com os entrevistados negros quanto brancos, mas todos permaneceram no mesmo nível de indefinição e hesitação. É interessante notar que Marta, não apenas é negra como tem antigas relações com movimentos negros. Mesmo assim, não emergiu uma forte correlação entre seu orixá pessoal e o pertencimento a um passado coletivo. É bastante provável que este seja um tema mais sensível que exige uma aproximação mais cuidadosa. É também de se imaginar que numa pesquisa conduzida nos terreiros "tradicionais" a questão da ancestralidade que vincula o indivíduo ao candomblé surja com força. No entanto, para essas pessoas de classe média cujas famílias não frequentavam a religião, o caso parece manter-se no nível de uma indefinição como a de Marta, pois mesmo entre Irene, Ernesto e Antônia, pessoas negras e membros de um terreiro antigo e considerado muito "tradicional”, não encontrei ressonância à questão.

Pode-se, então, dizer que o candomblé não oferece - ao menos para os adeptos de classe média - um palco para a elaboração de identidades coletivas bem definidas, pois não faz referência a uma história de um grupo bem delimitado. Evidentemente isto pode ser relacionado à história da escravização dos negros africanos e da reorganização de suas identidades em outro contexto sociocultural. (PRANDI, 1999) Num outro nível, pode ser relacionado à separação entre culto aos orixás e culto aos antepassados, baba Egun. Em ainda outro, pode ser relacionada organização descentralizada que mantém cada terreiro autônomo frente aos outros. (FRIGERIO, 2003) Por ora, no entanto, posso dizer que esta é uma religião que se volta para toda a humanidade e apresenta suas divindades como energias cósmicas.

Os orixás, portanto, não se apresentam como atualização do poder do passado de um povo concreto, mas e os caboclos? É interessante notar que estes vêm ao aiê para aconselhar, abençoar e tratar de seus seguidores. Mais ainda, os caboclos arranjam-se em categorias relacionadas a personagens da história brasileira. São os índios, donos originais desta terra (SANTOS, 1995), são os boiadeiros desbravadores dos sertões, são os marujos que atravessaram os mares. Dessa forma, 
assemelham-se às famílias de espíritos correlacionadas por Stoller (1997) à experiência histórica Songhay. Aproximam-se também do surgimento de uma categoria de espíritos, analisada por Ferrándiz (2004), no culto venezuelano María Lionza. Na década de 1990, num período de intensificação da pobreza e da violência urbana, esta forma de espiritismo (parecida com nossa umbanda) viu surgir a figura do Malandro - espíritos de jovens mortos violentamente, em geral ligados ao tráfico de drogas. Tal como os Hauka, os Malandros apresentavam uma face assustadora e, ao mesmo tempo, ofereciam proteção aos humanos envolvidos no culto. De modo semelhante ao de Stoller, Ferrándiz analisou a emergência destas entidades como uma forma encarnada de lidar com transformações sociais, evidenciando o caráter "histórico" das divindades.

Enquanto o poder dos orixás parece dizer mais respeito à existência universal, do mundo e do ser humano, o dos caboclos parece referir-se mais diretamente à particularidade de uma experiência histórica e, neste sentido, é interessante notar que, no dizer geral, “o caboclo vem para trabalhar". Ao que tudo indica, para uma ampla gama de adeptos do candomblé, o poder dos caboclos é mais diretamente sentido em suas vidas. Também é interessante a menção a um "Egun caboclo, baba Iaô" no culto a baba Egun de Ponta de Areia (Ilha de Itaparica) que encerra a festa e para o qual se canta em português e é um dos Eguns "mais festejados” daquele terreiro. (BRAGA, 1988a, p. 214)

Este é um ponto de contraste importante entre os membros das camadas populares e os adeptos de classe média que acompanhei. Como já foi dito, no Torrundê há culto aos caboclos e estes permanecem sempre como uma possibilidade para os filhos da casa. Boa parte daqueles focalizados nesta pesquisa de fato incorporam seus caboclos nas seções quinzenais. Mesmo assim, esta entidade não surgiu nas entrevistas com tanta ênfase como os orixás. Isto parece indicar, ao mesmo tempo, que a experiência histórica encarnada pelos caboclos encontra menor ressonância em suas vidas - ou encontra outras for- 
mas de atualização - e que a concepção das divindades como forças cósmicas individualizadas combina melhor com seu universo experiencial. A conclusão disto é que as próprias divindades encontramse enredadas no contexto social em que encarnam.

Isto, porém, não é o mesmo que dizer o "que está por trás da incorporação" dos orixás. Não é preciso descrer delas para fazer uma afirmação deste gênero. O ponto desta última análise é que o movimento exploratório pelo qual sujeitos engajam-se em seu mundo, constituindo simultaneamente este mundo e a si mesmos como sujeitos, é o mesmo que constitui as divindades enquanto tais. Isto significa que tal movimento informa um modo de voltar-se para as divindades, de relacionar-se com elas que as situa tanto quanto os indivíduos encontram-se situados socialmente. No mesmo sentido, podemos dizer que os orixás, ao existirem simultaneamente no mundo material e espiritual, têm que assumir uma forma de engajamento no primeiro quando encarnam em seus filhos. Ao incorporar nos iniciados, os orixás compartilham com eles uma forma de estar no mundo, de maneira semelhante à que Fábio utilizou para explicar como o orixá, ao ceder sua energia ao seu filho, cede também algumas de suas características. E neste mundo de classe média a individualidade é uma das formas de engajamento mais atuantes. 